\title{
Gelesen und dabei gedacht ...
}

\section{Werner Bauer}

Dr. med., Mitglied der Redaktion

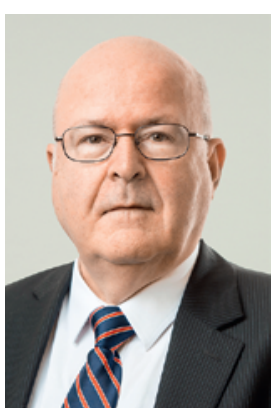

«Fernsehen bildet. Immer, wenn der Fernseher an ist, gehe ich in ein anderes Zimmer und lese.» (Groucho Marx)

In letzter Zeit habe ich bei schwarzem Bildschirm drei Texte gelesen, die zu guter Letzt auch breiteres Interesse finden dürften.

Unter dem Titel «Antiproduktivität heisst das neue Zauberwort» relativiert Rolf Dobelli in der NZZ (20.5.2017) den echten Nutzen technologischer Entwicklungen und hinterfragt, wie gross denn die gewonnene Produktivität des Autoverkehrs (gegenüber dem Fussmarsch oder Pferderitt), der E-Mail-Flut (gegenüber dem Briefwechsel), der PowerPoint-Folien-Salven (gegenüber Handnotizen und ein paar markanten Strichen auf einem Hellraumprojektor) und des Schiessens, Bearbeitens und Verwaltens ganzer Serien von Digitalbildern (gegenüber den guten alten Fotografien) sei. Seine Überlegungen sind provokativ, aber nicht unberechtigt: Mit Antiproduktivität bezeichnet er die Tatsache, «dass viele Technologien auf den ersten Blick Zeit und Geld sparen, diese Ersparnis sich dann aber in Luft auflöst, sobald man eine Vollkostenrechnung anstellt». Deshalb rät er zu einer Grundregel des guten Lebens: Was nicht wirklich etwas bringt, kann man sich sparen. Das gelte ganz besonders für Gadgets der Technologieindustrie.

Und dabei gedacht: Auch auf die Medizin lässt sich diese Empfehlung übertragen. Zwar erleben wir gerade heute echte, unverzichtbare Fortschritte, aber es gibt auch solche, die uns vorgegaukelt werden. Besonders wir Ärzte sind verpflichtet, neue oder abgeänderte Moleküle, erweiterte Indikationen und teure Methoden zunächst einmal kritisch zu hinterfragen.

Noch provokativer liest sich ein Interview in der $Z \ddot{u}$ richsee-Zeitung (1.6.2017) mit David van Reybrouck unter dem Titel «Wahlen schaffen bloss Eliten, nicht Demokratie». Er fordert, Volksvertreter per Los zu bestimmen, und geht zur Legitimierung bis auf Aristoteles zurück, der erkannt habe, dass Wahlen genau betrachtet zur Natur der Aristokratie gehören, das Losverfahren aber zur Natur der Demokratie. Er kritisiert, dass bei Wahlen die Breite der Gesellschaft nicht wirklich vertreten sei und dass die Entscheide der gewählten Gremien von den Parteien, die heute nur noch eine Minderheit des Volkes effektiv vertreten, und von Lob- bys, die noch weniger repräsentativ sind, massgeblich beeinflusst würden. In Irland habe eine ausgeloste Versammlung über die delikate Frage der Abtreibung in der Verfassung beraten und eine umsetzbare Empfehlung abgegeben. Eine entsprechende Volksinitiative für das schweizerische Parlament ist in Vorbereitung. Und dabei gedacht: Im Falle einer Auslosung der Parlamentarier ist zu vermuten, dass zumindest die heute überdimensionierte Zahl der Krankenkassen-Funktionäre sinken würde, was aus Ärztesicht kein Unglück wäre.

Ich legte die Zeitungen beiseite und durchstöberte ein informatives und irritierendes Buch, das mir empfohlen worden war: The Digital Doctor. Hope, Hype and Harm at the Dawn of Medicine's Computer Age, von Robert Wachter (McGraw-Hill Education, 2015). Der Platz reicht nur für einige kurze Zitate:

«The hospitals that are left standing will be large, bristling with technology, and, for the most part, embedded in megasystems.» «Patients will be in single rooms designed for safety and infection prevention. Each will be outfitted with wall-sized video screens as well as cameras capable of extreme close-ups (to allow a doctor to examine a patient's eyes or neck veins via video).» «The electronic health record will be transformed as well. The visit note will be created largely through speaking, rather than writing and clicking."

«Computerized decision support for clinicians will also be taken to a new level. Big-data analytics will be constantly at work.» "Consultations with specialists will be completely reimagined. If the inpatient doctors need a nephrology consultation, they will search online for a nephrologist who is available, and quickly arrange a videoconference.»

"As less time is wasted on documenting the care, doctors and nurses will have more direct contact with patients and families, restoring much of the joy in practice that has been eroding, like a coral reef, with each new wave of nonclinical demands.»

Und dabei gedacht: Angesichts der enormen, in Ausmass und Konsequenzen aber noch nicht klar abschätzbaren Entwicklungen ist das Klügste wohl ein Mix von etwas «Dobelli», viel Neugier und Offenheit, aber auch einer Dosis Optimismus. Entscheidend ist, dass die Ärzteschaft mitgestaltend dabei ist und nicht nur skeptisch-abwehrend hinterherhinkt. 